\title{
Disaccharides in the Treatment of Hepatic Encephalopathy in Patients with Cirrhosis
}

\author{
Praveen Sharma \\ Department of Hepatology, Institute of Liver and Biliary Sciences, \\ New Delhi, \\ India
}

\section{Introduction}

Hepatic encephalopathy (HE) is one of the major complications of liver cirrhosis. It has a considerable socioeconomic impact as it reduces the individual's quality of life and needs repeated admission in hospital for its treatment. HE is a complex neuropsychiatric syndrome, which may complicate acute or chronic liver failure and defined as a disturbance in central nervous system function because of hepatic insufficiency and after exclusion of other brain disease. Traditionally, HE is graded according to the West Haven criteria, which define HE grades I-IV based on the presence of specific clinical signs and symptoms and their severity $(1,2)$. The Working Party proposed a nomenclature of HE and classified into three types : type A, associated with acute liver failure; type B, associated with the existence of porto-systemic communications without intrinsic liver disease; and type $C$, associated with cirrhosis, which, depending on the manner of presentation, is classified into episodic HE (related to precipitating factors) or spontaneous (persistent HE)(1). However, patients with cirrhosis present with a continuous severity spectrum of neuropsychological symptoms ranging from entire normality (HE 0) up to obvious deficits (3). Even in minimal HE (MHE) without obvious clinical symptoms, neuropsychological and neurophysiological testing uncovers deficits which impact on the quality of life and the fitness to drive a motor vehicle (4-7).In this article we will focus mainly on treatment of HE related to cirrhosis (type-C) using disaccharides.

\section{Pathophysiology of HE and role of ammonia}

The pathogenesis of HE in cirrhosis is complex and has multiple components, including ammonia, inflammatory cytokines, benzodiazepine-like compounds, and manganese, that cause functional impairment of neuronal cells. Numerous factors have been shown to precipitate HE including infections, sedatives, gastrointestinal bleeding, dietary protein excess, diuretics, and electrolyte imbalance (8)

There is consensus that ammonia is a key toxin in HE, which may sensitize the brain to the different precipitating factors $(9,10)$. Ammonia is created primarily from nitrogenous products in the diet, bacterial metabolism of urea and proteins in the colon, and from deamination of glutamine in the small intestine by the enzyme glutaminase $(11,12)$. Due to 
hepatocellular dysfunction and portosystemic collaterals in cirrhosis, the ammonia concentration rises in the bloodstream and crosses the blood-brain barrier. Exposure to ammonia results in structural alterations in neurons manifested primarily as astrocyte swelling resembling Alzheimer type II astrocytosis $(13,14)$.In chronic liver disease, urea synthesis is impaired and the brain acts as an alternative major ammonia detoxification pathway. Astrocytes have the ability to eliminate ammonia by the synthesis of glutamine through amidation of glutamate by the enzyme glutamine synthetase (15-18). Glutamine enters the mitochondria (Trojan horse hypothesis) and is subsequently cleaved by glutaminase to ammonia and glutamate, thereby increasing intracellular ammonia levels. This causes a feed-forward loop as elevation in mitochondrial ammonia causes production of reactive nitrogen and oxygen species (RNOS) leading to further edema(19-22).Studies have also examined the role of ammonia-induced potentiation of aquaporin- 4 , a water channel expressed copiously in astrocytes(23). Astrocyte edema also causes depletion of taurine, a molecule that serves as an antioxidant and helps to buffer ammonia-induced toxicity(24).Increased ammonia levels cause abnormal cerebral blood flow and glucose metabolism. Single photon emission computed tomographic (SPECT) studies have demonstrated altered cerebral perfusion with hyperammonemia resulting in a redistribution of blood flow from the cortex to the subcortical regions, which was associated with impaired performance on neuropsychiatric testing(25). Further support for the ammonia-glutaminebrain water hypothesis has been provided by inducing hyperammonemia in patients with cirrhosis through the oral administration of an amino acid solution. An increase in brain glutamine, reduction in magnetization transfer ratio, and significant deterioration in neuropsychological function was suggestive of an increase in brain water (26).

\section{Treatment of HE}

The most important aspect of HE management is prompt recognition and treatment of precipitating factors. Fessel and colleagues demonstrated that HE is caused by reversible factors in over $80 \%$ of patients(27). These common reversible factors include constipation, infection, hypokalemia, gastrointestinal bleeding, increased protein intake, sedatives, and tranquilizers. Thus, identifying and correcting the reversible precipitating factors can be beneficial in treating most episodes of HE. Administration of various ammonia-lowering therapies such as nonabsorbable disaccharides and selected antimicrobial agents and other less utilized alternative and investigational treatment options include administration of benzodiazepine receptor antagonists, branched-chain amino acids (BCAAs) and ornithine aspartate. If infection is suspected or the patient has clinical evidence of ascites, a paracentesis should be performed with analysis of cell count, gram stain, and culture to evaluate for spontaneous bacterial peritonitis. Additional investigations for infection should be performed with blood cultures, urinalysis, or chest radiographs. Broadspectrum antibiotics should be initiated after obtaining cultures if infection is suspected, especially in patients with stage III or IV HE. Hypokalemia can be corrected with oral or intravenous potassium. Severe hyponatremia, particularly serum sodium less than $120 \mathrm{mEq} / \mathrm{L}$, should be addressed with appropriate free-water restriction(28). Vasopressin receptor antagonists may be considered for symptomatic patients with severe hyponatremia. HE precipitated by dietary protein intake or use of sedatives often resolves gradually with supportive care $(29,30)$. 


\section{Non-absorbable disaccharides and mechanism of action}

Non-absorbable disaccharides are recommended as first-line pharmacotherapy in current guidelines(2,28).

Current therapies for HE are based on ammonia lowering, with the hypothesis that the colon is the primary organ that generates ammonia $(2,28)$. Lactulose is the most commonly utilized non-absorbable disaccharide for HE. Lactulose, a synthetic disaccharide, is comprised of the monosaccharides lactose and galactose, and is available as a syrup. Doses are generally titrated to achieve two to four semi-soft stools daily, with typical doses of $20 \mathrm{~g} / 30 \mathrm{~mL}$ orally three to four times per day. A second non-absorbable disaccharide, lactitol, has also been used in the treatment of HE, but it is not currently commercially available in some countires like US(31,32). Lactitol (p-galactosido-sorbitol) is a disaccharide analog of lactulose which is neither absorbed nor broken down in the small intestine, but is extensively metabolized by colonic bacteria. It is available in a highly soluble crystalline powder form and is reported to be less sweet in taste than lactulose. Clinical trials have reported lactitol dosages of 10-12 g every 6 hours, titrated to two bowel movements daily to be effective in treatment of HE (31,33). Disaccharides (both lactulose and lactitol) remain undigested until they reach the colon, where they get metabolized by the bacteria in the colon to acetic and lactic acid. This acidification of colonic lumen inhibits bacterial ammonia production and trap ammonia as non-diffusable ammonium in the intestinal lumen.Due to their cathartic effect it facilitates a 4-fold increase in faecal nitrogen excretion. Both effects result in reduced levels of ammonia in the colon and portal blood. (Figure-1)(34-36).

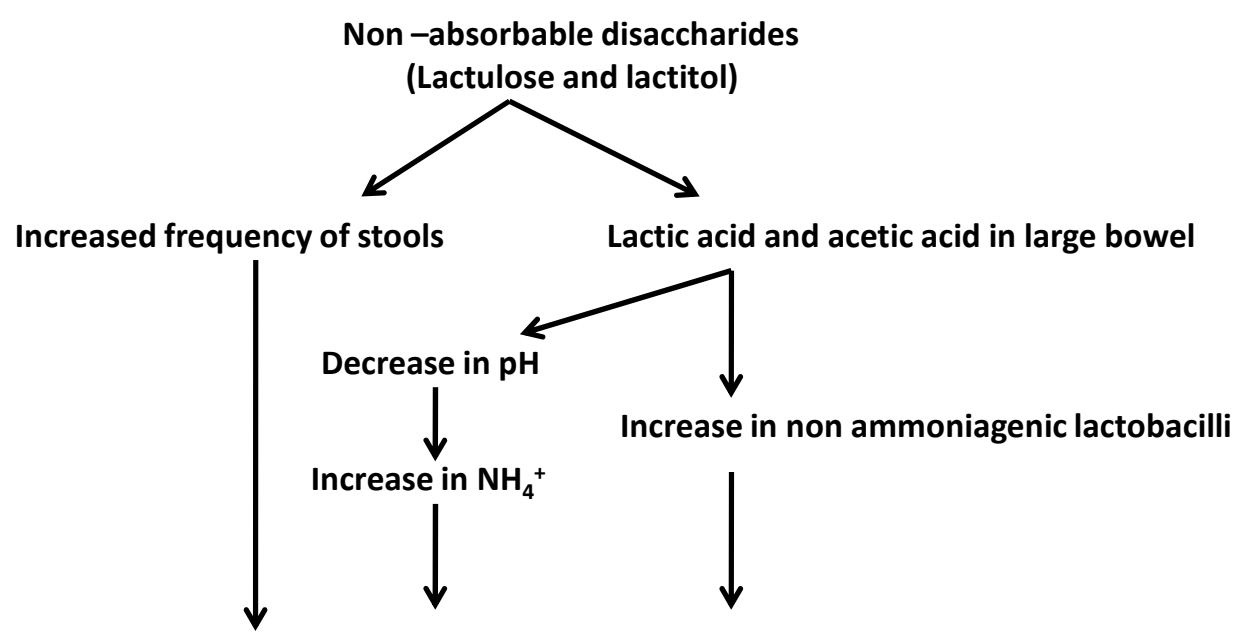

Decrease in ammonia absorption

Fig. 1. Mechanism of actions of disaccharides. 


\section{Clinical efficacy of non-absorbable disaccharides}

\subsection{Lactulose or lactitol versus placebo or no intervention}

\subsubsection{Overt hepatic encephalopathy}

The non-absorbable disaccharides have been a mainstay of therapy for HE for decades, and have been extensively studied in several small clinical trials since the late 1960s for this indication. In most of these trials patients had cirrhosis with acute, chronic, acute or chronic or minimal hepatic encephalopathy (37-44). Oral lactulose was used in majority of these studies though some had used lactitol and lactulose enemas also (40). In most of the studies the daily mean doses of lactulose ranged from $30 \mathrm{~g}$ to $80 \mathrm{~g}$ (median $50 \mathrm{~g}$ ) to obtain two to three semisoft stools per day. The median duration of treatment was 15 days (range 5 to 360 days). None of the trials followed up patients after the end of treatment. Uribe M et al (40) performed a double-blind, controlled trial to study the efficacy of acidifying enemas of lactitol and lactose versus nonacidifying tap-water enemas in 45 episodes of acute portalsystemic encephalopathy. A favorable response to treatment was obtained in 19 (86\%) of the patients receiving lactitol enemas and in $14(78 \%)$ of those receiving lactose enemas. They concluded that acidifying agents like lactose and lactitol are effective and superior to tapwater enemas for the treatment of acute nitrogenous portal-systemic encephalopathy. Study by Mas et al(45) in 53 patients with acute hepatic encephalopathy which were treated with lactitol $60 \mathrm{~g} /$ day for $5-10$ days concluded lactitol to be effective in $81 \%$ of patients. A recent meta-analysis evaluated 22 clinical trials in order to better assess the utilization of nonabsorbable disaccharides in the management of HE when compared with placebo, no intervention or antimicrobials. Compared with placebo or no intervention, lactulose and lactitol seemed to reduce the risk of no improvement of hepatic encephalopathy (relative risk $0.62,95 \%$ confidence interval 0.46 to 0.84 ). However high quality trials found no significant effect of lactulose or lactitol on the risk of no improvement (0.92, 0.42 to 2.04), whereas low quality trials found a significant beneficial effect of lactulose or lactitol $(0.57$, 0.40 to 0.83$)(46,47)$. At the present time, however, there is a lack of sufficient evidence to thoroughly refute the use of non-absorbable disaccharides for the treatment of HE. Sharma et al(48) had shown that high baseline model for end stage liver disease(MELD), high total leukocyte count, low serum sodium, low mean arterial pressure, and presence of hepatocellular carcinoma were predictors of nonresponse to lactulose.

\section{Disaccharides in treatment of minimal hepatic encephalopathy}

Trials in patients with minimal hepatic encephalopathy (MHE) found that lactulose or lactitol significantly reduced the risk of no improvement assessed by various psychometric tests $(0.61$, 0.47 to 0.79 ). Compared with placebo or no intervention, lactulose and lactitol had no significant effect on mortality but tended to lower blood ammonia. A summary analysis of some clinical trials of non-absorbable disaccharides versus placebo/ no treatment is shown in table-1.In a recent study Prasad et al(44) found that treatment with lactulose improved both cognitive function and health-related quality of life, as measured by the Sickness Impact Profile(SIP), when compared against a 'no treatment' patient group. The mean total SIP score improved among patients in the treated group (baseline, 10.39 [95\% CI 9.36-11.43]; after 3 months, 3.77 [95\% CI 2.52-5.02]) compared with patients in the untreated group (baseline, 10.36 [95\% CI 8.98-11.73]; after 3 months, 10.39 [95\% CI 8.36-12.42]); $\mathrm{p}=0.002$. Improvement in health related quality of life (HRQOL) was related to the improvement in psychometry. Study 
by Sharma et al had shown that on univariate and multivariate analysis, serum sodium and venous ammonia were the only two parameters associated with nonresponse to lactulose(49). Reported adverse events were not serious, and all originated from the gastrointestinal tract (diarrhoea, flatulence, abdominal pain, or nausea)(46).

\begin{tabular}{|c|c|c|c|c|c|c|}
\hline Trial & \begin{tabular}{|l|}
$\begin{array}{l}\text { Study } \\
\text { design }\end{array}$ \\
\end{tabular} & Patients & No & treatment & Assessment & Efficacy \\
\hline $\begin{array}{l}\text { Simmons et } \\
\text { al }(1970)(37)\end{array}$ & Parallel & $\mathrm{AHE}+\mathrm{CHE}$ & 26 & $\begin{array}{l}\text { Lactulose } \\
\text { / glucose }\end{array}$ & $\begin{array}{l}\text { Clinical grading, } \\
\text { ammonia, stool } \\
\text { production }\end{array}$ & $\begin{array}{l}\text { Lactulose= } \\
\text { glucose }\end{array}$ \\
\hline \begin{tabular}{|l} 
Rodgers et al \\
$(1973)(38)$
\end{tabular} & Crossever & $\mathrm{CHE}$ & 6 & $\begin{array}{l}\text { Lactulose } \\
\text { / sorbitol }\end{array}$ & $\begin{array}{l}\text { Clinical grading, } \\
\text { EEG, Ammonia }\end{array}$ & $\begin{array}{l}\begin{array}{l}\text { Lactuose= } \\
\text { sorbitol }\end{array} \\
\end{array}$ \\
\hline $\begin{array}{l}\text { Corazza et } \\
\text { al(1982)(39) }\end{array}$ & Parallel & $\mathrm{CHE}$ & 32 & $\begin{array}{l}\text { Lactulose } \\
\text { / placebo }\end{array}$ & $\begin{array}{l}\text { Encephalopathy } \\
\text { intensity score, } \\
\text { ammonia }\end{array}$ & $\begin{array}{l}\text { Lactulose } \\
\text { better than } \\
\text { placebo }\end{array}$ \\
\hline $\begin{array}{l}\text { Uribe et al } \\
(1987)(40)\end{array}$ & Parallel & AHE & 15 & $\begin{array}{l}\begin{array}{l}\text { Lactulose } \\
\text { enema }\end{array} \\
\end{array}$ & $\begin{array}{l}\text { Mortality, clinical } \\
\text { grading }\end{array}$ & $\begin{array}{l}\text { Lactulose> } \\
\text { placebo }\end{array}$ \\
\hline $\begin{array}{l}\text { Horsmans et } \\
\text { al (1997)(41) }\end{array}$ & Parallel & MHE & 14 & $\begin{array}{l}\text { Lactulose } \\
\text { / placebo }\end{array}$ & $\begin{array}{l}\text { Psychometric tests, } \\
\text { ammonia levels }\end{array}$ & $\begin{array}{l}\text { Lactulose > } \\
\text { placebo }\end{array}$ \\
\hline $\begin{array}{l}\text { Wantabe et } \\
\text { al (1997)(42) }\end{array}$ & Parallel & MHE & 36 & $\begin{array}{l}\text { Lactulose } \\
\text { / no treatment }\end{array}$ & $\begin{array}{l}\text { Three psychometric } \\
\text { tests, ammonia }\end{array}$ & $\begin{array}{l}\text { Lactulose > } \\
\text { placebo }\end{array}$ \\
\hline \begin{tabular}{|l|}
$\begin{array}{l}\text { Dhiman et al } \\
(2000)(43)\end{array}$ \\
\end{tabular} & Parallel & MHE & 26 & $\begin{array}{l}\text { Lactulose } \\
\text { / no treatment }\end{array}$ & psychometric tests & $\begin{array}{l}\text { Lactulose > } \\
\text { placebo }\end{array}$ \\
\hline $\begin{array}{l}\text { Prasad et al } \\
(2007)(44)\end{array}$ & Parallel & MHE & 61 & $\begin{array}{l}\text { Lactulose } \\
/ \text { no treatment }\end{array}$ & $\begin{array}{l}\text { psychometric tests } \\
\text { and HRQOL }\end{array}$ & $\begin{array}{l}\text { Lactulose > } \\
\text { placebo }\end{array}$ \\
\hline
\end{tabular}

AHE: acute hepatic encephalopathy CHE: Chronic hepatic encephalopathy

MHE: Minimal hepatic encephalopathy EEG: Electroencephalography

Table 1. Comparison of non absorbable disaccharides and placebo or no treatment for hepatic encephalopathy.

\section{Lactulose versus lactitol for the treatment of hepatic encephalopathy}

Lactulose and lactitol both have been used for the treatment of HE and lactulose has been compared with lactitol in various studies (32,33,50-57)(Table-2).Morgan et al(32) enrolled twenty-five cirrhotic patients experiencing 28 episodes of acute hepatic encephalopathy which were randomized blindly to treatment with either lactitol $(n=15)$ or lactulose $(n=13)$. At the end of the trial, $67 \%$ of the patients in the lactitol group and $69 \%$ of the lactulose group were clinically normal. Metaanalysis by Blanc et al(56) studied the efficiency and tolerance of both compounds(lactulose and lactitol) by using a meta-analysis on the basis of published controlled trials. Analyzed parameters were the portosystemic encephalopathy index of Conn after treatment, the percentage of improved patients and the percentage of patients who had ill effects related to the treatment (flatulence, diarrhea). Bibliographical screening revealed five studies comparing the effects of lactitol and lactulose in chronic hepatic encephalopathy. Four crossover studies were done that included 48 patients and one parallel study that included 29 patients. The duration of the treatment ranged from 3 to 6 months. All studies found a similar efficiency with both drugs. However, they exhibited some discrepancies in the relative frequency of adverse reactions (flatulence). 
Meta-analysis showed no statistical differences in the portosystemic encephalopathy index after lactitol or lactulose treatment. The percentage of improved patients after lactitol or lactulose was similar. In contrast, the analysis revealed a higher frequency ( $p$ less than 0.01 ) of flatulence in patients treated with lactulose compared with those treated with lactitol(56). In conclusion, this meta-analysis shows no statistical difference between therapeutic effects of lactitol and lactulose, but it does show a higher frequency of flatulence with lactulose. However another metaanalysis by Camma et al (57) showed that lactitol was as effective as other disaccharides in the treatment of encephalopathy: pooled odds ratio was $0.83,95 \%$ confidence interval was 0.38-1.82. Patients experienced fewer side effects during treatment with lactitol, but the pooled odds ratio was not statistically significant. In all studies lactitol was considered more palatable $(50,55)$. Clinical effectiveness of lactitol, in long-term treatment of chronic encephalopathy, is similar to those of lactulose. It seems that lactitol has lower side effects than lactulose.

\begin{tabular}{|l|l|l|l|l|l|l|}
\hline Trial & Study design & Patients & No & $\begin{array}{l}\text { Treatment } \\
\text { duration }\end{array}$ & Assessment & Efficacy \\
\hline $\begin{array}{l}\text { Lanthier et } \\
\text { al (1985)(50) }\end{array}$ & Crossover & CHE & 5 & 6 months & $\begin{array}{l}\text { Clinical examination, } \\
\text { psychometric tests, } \\
\text { ammonia levels, EEG, } \\
\text { cerebral blood flow }\end{array}$ & $\begin{array}{l}\text { Lactulose } \\
\text { =lactitol }\end{array}$ \\
\hline $\begin{array}{l}\text { Morgan and } \\
\text { Hawley et } \\
\text { al(1987)(32) }\end{array}$ & $\begin{array}{l}\text { Parallel, } \\
\text { double blind }\end{array}$ & AHE & 25 & 5 days & $\begin{array}{l}\text { Psychometric tests, } \\
\text { EEG, PSE index }\end{array}$ & $\begin{array}{l}\text { Lactulose } \\
\text { =lactitol }\end{array}$ \\
\hline $\begin{array}{l}\text { Heredia et } \\
\text { al(1987)(51) }\end{array}$ & Parallel & AHE & 40 & 5 days & $\begin{array}{l}\text { Mortality, clinical } \\
\text { grading, PSE grade, } \\
\text { adverse events }\end{array}$ & $\begin{array}{l}\text { Lactulose } \\
\text { =lactitol }\end{array}$ \\
\hline $\begin{array}{l}\text { Heredia et } \\
\text { al(1988)(34) }\end{array}$ & $\begin{array}{l}\text { Randomized, } \\
\text { crossover }\end{array}$ & CHE & 25 & 6 months & $\begin{array}{l}\text { Psychometric tests, } \\
\text { ammonia levels, EEG, } \\
\text { PSE index }\end{array}$ & $\begin{array}{l}\text { Lactulose } \\
\text { =lactitol }\end{array}$ \\
\hline $\begin{array}{l}\text { Morgan et } \\
\text { al(1989)(52) }\end{array}$ & $\begin{array}{l}\text { Double-blind, } \\
\text { randomized, } \\
\text { Crossover }\end{array}$ & MHE & 9 & 3 months & $\begin{array}{l}\text { Psychometric tests, } \\
\text { ammonia levels, EE }\end{array}$ & $\begin{array}{l}\text { Lactulose } \\
\text { =lactitol }\end{array}$ \\
\hline $\begin{array}{l}\text { Riggio et al } \\
\text { 1989(53) }\end{array}$ & Parallel & $\begin{array}{l}\text { CHE + } \\
\text { MHE }\end{array}$ & 31 & 6 months & $\begin{array}{l}\text { PSE Index, new } \\
\text { episodes of HE, } \\
\text { adverse events }\end{array}$ & $\begin{array}{l}\text { Lactulose } \\
\text { =lactitol }\end{array}$ \\
\hline $\begin{array}{l}\text { Grandi } \\
\text { 1991(54) }\end{array}$ & Cross-over & CHE & 40 & - & $\begin{array}{l}\text { PSE Index, adverse } \\
\text { events }\end{array}$ & $\begin{array}{l}\text { Lactulose } \\
\text { =lactitol }\end{array}$ \\
\hline $\begin{array}{l}\text { Pai et al } \\
1995(55)\end{array}$ & Parallel & AHE & 45 & 5 days & $\begin{array}{l}\text { PSE Index, adverse } \\
\text { events }\end{array}$ & $\begin{array}{l}\text { Lactitol>la } \\
\text { ctulose }\end{array}$ \\
\hline $\begin{array}{l}\text { Blanc P et al } \\
\text { 1992(56) }\end{array}$ & Metaanalysis & CHE & 77 & $3-6$ months & PSE Index & $\begin{array}{l}\text { Lactulose } \\
=\text { lactitol }\end{array}$ \\
\hline $\begin{array}{l}\text { Cammà C et } \\
\text { al 1993(57) }\end{array}$ & Metaanalysis & CHE & - & - & PSE Index & $\begin{array}{l}\text { Lactulose } \\
\text { =lactitol }\end{array}$ \\
\hline
\end{tabular}

AHE: acute hepatic encephalopathy CHE: Chronic hepatic encephalopathy

MHE: Minimal hepatic encephalopathy PSE Index: Portosystemic encephalopathy index

Table 2. Comparison of lactulose and lactitol for hepatic encephalopathy. 


\section{Comparison of lactulose and antimicrobial agents for hepatic encephalopathy}

Certain oral antibiotics can reduce urease-producing bacteria in the intestines, resulting in a decrease of ammonia production and absorption through the gastrointestinal tract. Antibiotics are used generally in patients who do not tolerate nonabsorbable disaccharides or in patients who are symptomatic on nonabsorbable disaccharides and require a second agent. Antibiotics with activity against urease-producing bacteria (e.g. neomycin, metronidazole) are effective in reducing intestinal ammonia production. However, the safety and efficacy of these antibiotics in treatment of HE have not been adequately demonstrated. Neomycin and other antimicrobials are utilized as a treatment modality in HE due to their ability to inhibit ammonia production by intestinal bacteria(58). Conn et al(58) conducted a randomized double blind clinical comparison of neomycin and lactulose in 33 cirrhotic patients with chronic portal-systemic encephalopathy. Serial assessments were made in all patients regarding mental status, asterixis, trailmaking test (TMT), electroencephalograms (EEG) and arterial ammonia levels. Both neomycin-sorbitol and lactulose were effective in the majority of patients (83 and $90 \%$, respectively. Atterbury et al (59) evaluated in double-blind, randomized study the efficacy of lactulose and compared with neomycin-sorbitol in 45 episodes of acute nitrogenous portal-systemic encephalopathy (PSE) induced by dietary protein, azotemia, or gastrointestinal hemorrhage. All patients had underlying cirrhosis, and at the time of randomization had encephalopathy of at least grade 2 severity and arterial ammonia concentrations greater than 150 microgram/100 ml. Two thirds of the patients in each group returned to normal mental status and more than $80 \%$ in each group showed at least one grade improvement in mental state. In addition, there was equivalent improvement in asterixis, in the performance of the Number Connection Test, in the electroencephalographic pattern, and in arterial ammonia concentration. The principal difference between the two groups was a greater reduction in stool $\mathrm{pH}$ after lactulose therapy than after neomycin-sorbitol therapy. Other antimicrobials, including metronidazole and vancomycin, have been studied to a more limited extent than neomycin(59-61)(Table-3). Orlandi et al (60) conducted a randomized

\begin{tabular}{|l|l|l|l|l|l|}
\hline Trial & Study design & $\begin{array}{l}\text { No of } \\
\text { patients }\end{array}$ & $\begin{array}{l}\text { Duration of } \\
\text { treatment }\end{array}$ & Assessment & Efficacy \\
\hline $\begin{array}{l}\text { Conn et } \\
\text { al(1977)(58) }\end{array}$ & $\begin{array}{l}\text { Neomycin vs } \\
\text { lactulose } \\
\text { (double-blind, } \\
\text { randomized, } \\
\text { crossover) }\end{array}$ & 29 & $\begin{array}{l}10 \text { days } \\
\text { each } \\
\text { arm before } \\
\text { crossover }\end{array}$ & $\begin{array}{l}\text { Mental status, } \\
\text { asterixis } \\
\text { score, EEG, ammonia } \\
\text { levels, PSE index }\end{array}$ & $\begin{array}{l}\text { Neomycin }= \\
\text { lactulose }\end{array}$ \\
\hline $\begin{array}{l}\text { Atterbury et } \\
\text { al(1978)(59) }\end{array}$ & Parallel & 47 & 7 days & $\begin{array}{l}\text { Mental status, } \\
\text { asterixis } \\
\text { score, EEG, ammonia } \\
\text { levels, PSE index }\end{array}$ & $\begin{array}{l}\text { Neomycin = } \\
\text { lactulose }\end{array}$ \\
\hline $\begin{array}{l}\text { Orlandi et } \\
\text { al(1981)(60) }\end{array}$ & Single blind & 173 & 14 days & $\begin{array}{l}\text { Mental status, } \\
\text { asterixis } \\
\text { score, EEG, ammonia } \\
\text { levels, HE change }\end{array}$ & $\begin{array}{l}\text { Neomycin = } \\
\text { lactulose }\end{array}$ \\
\hline
\end{tabular}

EEG: Electroencephalography

Table 3. Comparison of lactulose and neomycin for hepatic encephalopathy. 


\begin{tabular}{|c|c|c|c|c|c|}
\hline Trial & Study design & $\begin{array}{l}\text { No of } \\
\text { patients }\end{array}$ & $\begin{array}{l}\text { Duration of } \\
\text { treatment }\end{array}$ & Assessment & Efficacy \\
\hline $\begin{array}{l}\text { Festi et } \\
\text { al(1993)(64) }\end{array}$ & $\begin{array}{l}\text { Lactulose } \\
\text { (open-label) }\end{array}$ & 21 & 21 & $\begin{array}{l}\text { Neurological } \\
\text { signs of HE, } \\
\text { asterixis score, } \\
\text { HRNB, EEG, } \\
\text { ammonia levels }\end{array}$ & $\begin{array}{l}\text { Rifaximin } \\
=\text { lactulose }\end{array}$ \\
\hline $\begin{array}{l}\text { Bucci and } \\
\text { Palmieri } \\
(1993)(68)\end{array}$ & $\begin{array}{l}\text { Lactulose } \\
\text { (double-blind, } \\
\text { double- } \\
\text { dummy) }\end{array}$ & 58 & 15 & \begin{tabular}{|l|} 
Neurological \\
status, asterixis \\
score, HRNB, \\
cancellation tasks, \\
EEG, ammonia \\
levels
\end{tabular} & $\begin{array}{l}\text { Rifaximin } \\
>\text { lactulose }\end{array}$ \\
\hline $\begin{array}{l}\text { Massa } \\
\text { et al(1993)(70) }\end{array}$ & $\begin{array}{l}\text { Lactulose } \\
\text { (double-blind, } \\
\text { double- } \\
\text { dummy) } \\
\end{array}$ & 40 & 15 & $\begin{array}{l}\text { HE index severity, } \\
\text { mental status, } \\
\text { cancellation tasks, } \\
\text { HRNB, EEG }\end{array}$ & $\begin{array}{l}\text { Rifaximin } \\
>\text { lactulose }\end{array}$ \\
\hline $\begin{array}{l}\text { Fera et } \\
\text { al(1993)(72) }\end{array}$ & $\begin{array}{l}\text { Lactulose } \\
\text { (double-blind, } \\
\text { double- } \\
\text { dummy) }\end{array}$ & 40 & $\begin{array}{l}\text { First } 2 \text { weeks } \\
\text { of each month } \\
\text { for } 3 \text { months }\end{array}$ & $\begin{array}{l}\text { Mental status, } \\
\text { asterixis score, } \\
\text { cancellation } \\
\text { tasks, HRNB, } \\
\text { EEG, ammonia } \\
\text { levels, PSE } \\
\text { index }\end{array}$ & $\begin{array}{l}\text { Rifaximin } \\
>\text { lactulose }\end{array}$ \\
\hline $\begin{array}{l}\text { Mas et } \\
\text { al(2003)(71) }\end{array}$ & $\begin{array}{l}\text { Lactitol } \\
\text { (double-blind, } \\
\text { double- } \\
\text { dummy) }\end{array}$ & 103 & 5-10 days & $\begin{array}{l}\text { Mental status, } \\
\text { asterixis score, } \\
\text { EEG, } \\
\text { ammonia levels, } \\
\text { PSE index, } \\
\text { psychometric } \\
\text { tests }\end{array}$ & $\begin{array}{l}\text { Rifaximin } \\
=\text { lactitol }\end{array}$ \\
\hline $\begin{array}{l}\text { Leevy et } \\
\text { al(2007)(73) }\end{array}$ & $\begin{array}{l}\text { Lactulose } \\
\text { (crossover) }\end{array}$ & 145 & $\begin{array}{l}>6 \text { months } \\
\text { lactulose } \\
>6 \text { months } \\
\text { rifaximin }\end{array}$ & $\begin{array}{l}\text { HE grade, } \\
\text { asterixis score }\end{array}$ & $\begin{array}{l}\text { Rifaximin } \\
>\text { lactulose }\end{array}$ \\
\hline $\begin{array}{l}\text { Paik et } \\
\text { al(2005)(74) }\end{array}$ & $\begin{array}{l}\text { Lactulose } \\
\text { (open-label) }\end{array}$ & 54 & 7 days & $\begin{array}{l}\text { Ammonia levels, } \\
\text { flapping tremor, } \\
\text { mental } \\
\text { status, HE index, } \\
\text { psychometric tests }\end{array}$ & $\begin{array}{l}\text { Rifaximin } \\
=\text { lactitol }\end{array}$ \\
\hline $\begin{array}{l}\text { Jiang Q et } \\
\text { al(2008)(76) }\end{array}$ & meta-analysis & 264 & - & - & $\begin{array}{l}\text { Rifaximin } \\
=\text { lactitol }\end{array}$ \\
\hline
\end{tabular}

Table 4. Comparison of disaccharides and rifaximin for hepatic encephalopathy. 
study in order to compare the course of HE in patients treated with neomycin plus magnesium sulfate or with lactulose. The treatment groups were similar in terms of clinical characteristics, fatalities, recovery rate from grade 1 encephalopathy, and disappearance rate of neuropsychiatric signs. Transitions from severe to grade 1 or 0 encephalopathy showed a 0.17 (NS) difference in favor of neomycin. Early therapy and evidence of precipitating factors showed a favorable prognostic significance. Ascites, hyperbilirubinemia, poor nutritional state, and hypoprothrombinemia showed bad prognostic significance.

A combination of disaccharides and antibiotics is generally used in difficult to treat patients with HE, but clinical data is limited. In a retrospective chart review of 213 cases, Mantry and colleagues showed that the number of hospitalizations and the duration of hospital stays were shortened for patients receiving combination therapy compared with those receiving lactulose monotherapy. Additional studies to further investigate the potential therapeutic benefit of combination therapy will be needed. $(77,78)$

\section{Disaccharides versus other therapy for hepatic encephalopathy}

Mittal et al(79) compared lactulose, probiotics, and L-ornithine L-aspartate (LOLA) in treatment of MHE and effect on health related quality of life by Sickness Impact Profile questionnaire. MHE improved significantly in all three treatment groups. Lactulose, probiotics, and LOLA significantly improve MHE and health related quality of life in patients with chronic liver disease. Similar results were found in other studies $(80,81)$ Table-5

\begin{tabular}{|l|l|l|l|l|l|l|}
\hline Trial & $\begin{array}{l}\text { Study } \\
\text { design }\end{array}$ & $\begin{array}{l}\text { No of } \\
\text { patients }\end{array}$ & $\begin{array}{l}\text { Type of } \\
\text { patient }\end{array}$ & Treatment & assessment & Efficacy \\
\hline $\begin{array}{l}\text { Loguercio et al } \\
\text { 1987(82) }\end{array}$ & Parallel & 40 & CHE & $\begin{array}{l}\text { Lactobacillus } \\
\text { SF68 / } \\
\text { lactulose }\end{array}$ & $\begin{array}{l}\text { PSE } \\
\text { parameters, } \\
\text { adverse } \\
\text { events }\end{array}$ & SF68=lactulose \\
\hline $\begin{array}{l}\text { Loguercio et al } \\
\text { 1995(83) }\end{array}$ & Parallel & 40 & CHE & $\begin{array}{l}\text { Lactobacillus } \\
\text { SF68 / } \\
\text { lactulose }\end{array}$ & $\begin{array}{l}\text { PSE } \\
\text { parameters, } \\
\text { adverse } \\
\text { events }\end{array}$ & SF68=lactulose \\
\hline $\begin{array}{l}\text { Sushma et al } \\
\text { 1992(84) }\end{array}$ & Parallel & 74 & AHE & $\begin{array}{l}\text { Sodium } \\
\text { benzoate / } \\
\text { lactulose }\end{array}$ & $\begin{array}{l}\text { Mortality, } \\
\text { PSE } \\
\text { parameters }\end{array}$ & $\begin{array}{l}\text { Sodium } \\
\text { benzoate=lactulose }\end{array}$ \\
\hline $\begin{array}{l}\text { Fiaccadori } \\
\text { 1980(86) }\end{array}$ & Parallel & 23 & $\begin{array}{l}\text { AHE }+ \\
\text { CHE }\end{array}$ & $\begin{array}{l}\text { BCAA/BCA } \\
\text { A } \\
+ \text { lactulose / } \\
\text { lactulose }\end{array}$ & $\begin{array}{l}\text { Clinical } \\
\text { grading }\end{array}$ & $\begin{array}{l}\text { BCAA+lactulose> } \\
\text { BCAA/lactulose }\end{array}$ \\
\hline $\begin{array}{l}\text { Rossi- } \\
\text { Fanelli 1982(87) }\end{array}$ & Parallel & 40 & AHE & $\begin{array}{l}\text { BCAA / } \\
\text { lactulose }\end{array}$ & $\begin{array}{l}\text { Clinical } \\
\text { grading }\end{array}$ & BCAA=Lactulose \\
\hline
\end{tabular}

Table 5. Disaccharides versus other therapy for hepatic encephalopathy. 
Loguercio et al. (82) in 40 patients with cirrhosis on a dietary protein regimen of $1 \mathrm{~g} / \mathrm{kg}$ determined the effect on chronic hepatic encephalopathy of long-term administration of Enterococcus faecium (SF68) versus lactulose. The patients received one of the two treatments for three periods of 4 weeks, each separated by drug-free 2-week intervals. The efficacy of treatment was assessed by arterial blood ammonia concentration, mental status, number connection (Reitan's part A) test and flash-evoked visual potentials. At the end of the third period the reduction in both blood ammonia concentrations and Reitan's test times was more enhanced in patients on SF68 than in patients on lactulose. In conclusion, SF68 is at least as useful as lactulose for the chronic treatment of chronic hepatic encephalopathy; it has no adverse effects, and treatment can be interrupted for 2 weeks without losing the beneficial effects.

Sushma et al(84) conducted a prospective randomized double-blind study to evaluate the efficacy of sodium benzoate in the treatment of acute portal-systemic encephalopathy. Seventy-four consecutive patients with cirrhosis or surgical portasystemic anastomosis and hepatic encephalopathy of less than 7 days duration were randomized to receive lactulose (dose adjusted for 2 or 3 semiformed stools/day) or sodium benzoate (5 gm twice daily). Assessment of response included mental status, asterixis, arterial ammonia level, electroencephalogram and number-connection test. The incidence of side effects was similar in the two treatment groups. The cost of lactulose for one course of therapy was 30 times that of sodium benzoate. They concluded that sodium benzoate is a safe and effective alternative to lactulose in the treatment of acute portasystemic encephalopathy. However in a study by Efrati et al (85) Blood ammonia increased after the glutamine load both before (from $66 \pm 12 \mathrm{mg} / \mathrm{dl}$ to $123 \pm 34 \mathrm{mg} / \mathrm{dl}$ and $179 \pm 53 \mathrm{mg} / \mathrm{dl}$ after 30 and $60 \mathrm{~min}$, respectively; $\mathrm{p}<0.0004$ ) and after benzoate treatment (from $102 \pm 27 \mathrm{mg} / \mathrm{dl}$ to $185 \pm 49 \mathrm{mg} / \mathrm{dl}$ and $250 \pm 39$ $\mathrm{mg} / \mathrm{dl}$ after 30 and $60 \mathrm{~min}$, respectively; $\mathrm{p}<0.00001$ ). The Number Connection test and the Posner's test were not altered by benzoate treatment and this study suggests a note of caution in the use of sodium benzoate in cirrhotic patients.

Rossi-Fanelli $\mathrm{F}$ et al(87) conducted a controlled study in two groups of 20 cirrhotic patients with deep coma in order to compare the efficacy of intravenous branched-chain amino acid solutions in $20 \%$ glucose (group A) vs. lactulose plus glucose in isocaloric amount (group B). Complete mental recovery was obtained in $70 \%$ of patients in group $\mathrm{A}$ and in $47 \%$ in group B. They concluded that, branched-chain amino acids are at least as effective as lactulose in deep hepatic coma. However, in a meta-analysis of eleven randomised trials (556 patients) assessing BCAA versus carbohydrates, neomycin/lactulose, or isonitrogenous control. There was no significant evidence of an effect of BCAA on improvement of hepatic encephalopathy in trials with adequate generation of the allocation sequence (RR 1.01,95\% CI 0.84 to 1.23 , three trials), adequate allocation concealment (RR $1.09,95 \%$ CI 0.89 to 1.33 , five trials), or adequate double-blinding (RR 1.20, 95\% CI 0.83 to 1.73, three trials). So it was concluded that BCAA had no significant beneficial effect on patients with hepatic encephalopathy (88).

\section{Disaccharides for primary prophylaxis of hepatic encephalopathy}

Certain patients are at risk of development of HE like patients with minimal hepatic encephalopathy and those with advanced liver disease (89-91). Variceal bleed is an important precipitating factor for $\mathrm{HE}$ in patients with cirrhosis. In a randomized trial, (92) 
we enrolled seventy patients with acute variceal bleed into group-1(lactulose, $n=35$ ) and group-2 (no lactulose, $n=35)$. Nineteen $(27 \%)$ patients developed HE, 5 patients $(14 \%)$ in the lactulose and 14 patients $(40 \%)$ in no lactulose, $p=0.03$. On multivariate analysis, only baseline arterial ammonia, blood requirement during hospital stay and no lactulose therapy were predictors of development of HE. Hence, lactulose was effective in preventing HE in these patients. We therefore, recommend lactulose $(30-60 \mathrm{ml} /$ day) so that patients pass two to three semi formed stools in a day in these subsets of patients.

Recently our group has shown in a randomized trial (93) involving 120(48\%) patients, receiving either lactulose $(n=60)$ or no lactulose $(n=60)$. Twenty $(19 \%)$ of 105 patients followed for 12 mo developed an episode of overt HE. Six (11\%) of 55 in the lactulose group and $14(28 \%)$ of 50 in the no lactulose group $(\mathrm{p}=0.02)$ developed HE. Ten $(20 \%)$ of 50 patients no lactulose group and $5(9 \%)$ of 55 patients lactulose group died, $\mathrm{p}=0.16$. On multivariate analysis, Child's score and presence of MHE at baseline was significantly associated with development of HE. Lactulose is effective in the primary prevention of HE.

\section{Disaccharides for secondary prophylaxis of hepatic encephalopathy}

Hepatic encephalopathy may be a cyclic condition in which patients develop overt HE, receive treatment, enter remission, and relapse. The emergence of HE after transjugular intrahepatic portosystemic shunt (TIPS) is of major concern for patients undergoing this procedure for refractory ascites or for prevention of variceal rebleeding. This clinical complication tends to occur within the first few days post-procedure.

Although the majority of post-TIPS HE episodes are mild and responsive to pharmacological therapy, there are some cases where intractable HE develops and hospitalization is required. There are limited data on the use of drug therapy for the prophylaxis of HE after a TIPS procedure or in patients who have recovered from an episode of HE who may benefit from pharmacological prophylaxis to prevent future recurrences. Until recently, there has not been any conclusive evidence to support routine use of pharmacological prophylaxis for this purpose. Riggio and colleagues (94) conducted the first randomized controlled trial utilizing lactitol or rifaximin as pharmacological prophylaxis of post-shunt HE. Seventy-five consecutive patients with cirrhosis undergoing a TIPS procedure were randomized to receive lactitol $60 \mathrm{~mL} /$ day, rifaximin $1200 \mathrm{mg} /$ day or no treatment. Patients in the rifaximin or no-treatment groups were allowed administration of a sorbitol enema $(120 \mathrm{~mL})$ in cases of minimal bowel movement $(<1$ bowel movement/day). Treatments were continued for 1 month post-TIPS or until the occurrence of an episode of HE. There was no significant difference in rate of HE occurrence among the three patient groups $(\mathrm{p}=0.97)$.

Two recent clinical trials have been conducted to evaluate the efficacy of lactulose or rifaximin used concomitantly with lactulose, as secondary prophylaxis of overt HE compared with placebo $(95,96)$. Sharma and colleagues(95) conducted a single-centre, openlabel, randomized controlled trial in 125 cirrhotic patients who had recovered from at least one previous episode of HE. Patients were randomized to receive either lactulose 30$60 \mathrm{~mL} /$ day or placebo. Development of overt HE was the primary study endpoint. At the end of a median follow-up time of 14 months, significantly more patients in the placebo group (30 of 64 patients [46.8\%]) than in the lactulose group (12 of 61 patients [19.6\%]) developed HE ( $p=0.001)$. 
In a recent multicenter double blind randomized clinical trial to assess the secondary prevention of HE Bass and colleagues(96), enrolled 299 cirrhotic patients with a history of at least two episodes of overt HE to receive either rifaximin (550 mg twice daily; $\mathrm{n}=140$ ) or placebo $(n=159)$ for a period of 6 months. All enrolled patients had Model for End-Stage Liver Disease (MELD) scores of <25. More than $90 \%$ of patients in both groups were also maintained on concomitant lactulose therapy. A significantly lower percentage of patients in the rifaximin group $(22.1 \%)$ experienced a breakthrough HE episode during the study period than in the placebo group (45.9\%), with a hazard ratio (HR) of 0.42 (95\% CI 0.28, 0.64; $<0.001)$. In addition, there was a significantly reduced risk of hospitalization due to hepatic encephalopathy in the rifaximin patient group when compared with placebo; 19 patients in the rifaximin group $(13.6 \%)$ versus 36 patients in the placebo group $(22.6 \%),(p=0.01)$. No significant difference in the incidence of adverse events was found between the two groups. In a similar study by Sanyal et al(97) patients with cirrhosis in remission from HE (Conn score = 0 or 1$)$ and a documented history of recurrent HE episodes ( $\geq 2$ within 6 months of screening) were randomised to rifaximin $550 \mathrm{mg}$ twice daily $(\mathrm{N}=101)$ or placebo $(\mathrm{N}=118)$ for 6 months. Concomitant lactulose was permitted during the study. The Chronic Liver Disease Questionnaire (CLDQ) was administered every 4 weeks, and time for occurrence of HE breakthrough was recorded. The time-weighted averages of the overall CLDQ score and each domain score were significantly higher in the rifaximin group vs. placebo (P-values ranged from 0.0087 to 0.0436 ); and were significantly lower in patients who experienced HE breakthrough compared to those who remained in remission (P-values were $<0.0001$ )(Table-6). Hence lactulose and rifaximin for the secondary prophylaxis of $\mathrm{HE}$ is recommended.

\begin{tabular}{|l|l|l|l|l|l|}
\hline Trial & Study design & $\begin{array}{l}\text { No of } \\
\text { patients }\end{array}$ & $\begin{array}{l}\text { Duration of } \\
\text { treatment }\end{array}$ & assessment & Efficacy \\
\hline $\begin{array}{l}\text { Sharma BC } \\
\text { et al } \\
(2009)(69)\end{array}$ & $\begin{array}{l}\text { Lactulose (open- } \\
\text { label) }\end{array}$ & 140 & 14 months & $\begin{array}{l}\text { Psychometry } \\
\text { and CFF }\end{array}$ & $\begin{array}{l}\text { Lactulose> } \\
\text { no treatment }\end{array}$ \\
\hline $\begin{array}{l}\text { Bass et al } \\
(2010)(70)\end{array}$ & $\begin{array}{l}\text { Rifxaximin+lactulose } \\
\text { (randomized, } \\
\text { double-blind, } \\
\text { placebo-controlled) }\end{array}$ & 299 & 6 months & HE clinical & $\begin{array}{l}\text { Rifaximin } \\
\text { >placebo }\end{array}$ \\
\hline
\end{tabular}

Table 6. Disaccharides for secondary prophylaxis of hepatic encephalopathy.

\section{Conclusion}

Current pharmacotherapy for the management of HE is fairly limited, mainly because of the complex and relatively limited understanding of the pathophysiology of the disorder. Although the evidence of ammonia is robust, in everyday clinical practice a consistent correlation between the concentration of ammonia in the blood and the manifest symptoms of $\mathrm{HE}$ is not observed. More recently the synergistic role of inflammation and infection in modulating the cerebral effects of ammonia has been shown to be important. The most commonly utilized pharmacological agents include the non-absorbable disaccharides lactulose and lactitol, and the antimicrobial agent rifaximin. Lactulose and lactitol, the synthetic compounds of lactose, are poorly absorbed from the small intestine, and both are almost exclusively metabolized by the bacterial flora of the colon. These disaccharides 
shorten the small bowel transit time mechanically and lower the $\mathrm{pH}$ of the bowel, both by their osmotic effects and by the acidic $\mathrm{pH}$ of their metabolites hence diminish the absorption of ammonia. Lactulose and lactitol are the classical therapy of choice for the treatment of hepatic encephalopathy. Recent literature has questioned the clinical efficacy of disaccharides in improving morbidity and mortality in patients with $\mathrm{HE}$ and, although antimicrobial agents such rifaximin have had an established role in the treatment of low grade (West Haven grade 1 and 2) encephalopathy, its use in high grade HE (grade 3 and 4) needs more data. Till we have more definitive agents non-absorbable disaccharides lactulose still continues to be the first line therapy for the prevention, treatment and secondary prophylaxis of hepatic encephalopathy.

\section{References}

[1] Ferenci P, Lockwood A, Mullen K, Tarter R, Weissenborn K, Blei AT. Hepatic encephalopathy- definition, nomenclature, diagnosis, and quantification: final report of the working party at the 11th World Congresses of Gastroenterology, Vienna, 1998. Hepatology 2002;35:716-721

[2] Riordan SM, Williams R. Treatment of hepatic encephalopathy. N Engl J Med 1997;337:473- 479 .

[3] Bajaj JS, Wade JB, Sanyal AJ. Spectrum of neurocognitive impairment in cirrhosis: Implications for the assessment of hepatic encephalopathy Hepatology. 2009 Dec;50(6):2014-21

[4] Bajaj JS, Hafeezullah M, Hoffmann RG, Saeian K. Minimal hepatic encephalopathy: a vehicle for accidents and traffic violations. Am J Gastroenterol 2007;102:1903-9

[5] Groeneweg M, Quero JC, De Bruijn I, Hartmann IJC, Essink-bot MI, Hop WCJ et al. Subclinical hepatic encephalopathy impairs daily functioning. HEPATOLOGY 1998;28:45-9

[6] Bajaj JS, Stein AC, Dubinsky RM. What Is Driving the Legal Interest in Hepatic Encephalopathy? Clin Gastroenterol Hepatol. 2010 Nov 9

[7] Bajaj JS, Saeian K, Schubert CM, Hafeezullah M, Franco J et al Minimal hepatic encephalopathy is associated with motor vehicle crashes: the reality beyond the driving test Hepatology. 2009 Oct;50(4):1175-83

[8] Haussinger D, Schliess F. Pathogenetic mechanisms of hepatic encephalopathy. Gut 2008;57:1156-65

[9] Bismuth M, Funakoshi N, Cadranel JF, Blanc P. Hepatic encephalopathy: from pathophysiology to therapeutic management Eur J Gastroenterol Hepatol. 2011 Jan;23(1):8-22

[10] Albrecht J, Zielińska M, Norenberg MD Glutamine as a mediator of ammonia neurotoxicity: A critical appraisal. Biochem Pharmacol. 2010 Nov 1;80(9):1303-8

[11] Gerber T, Schomerus H. Hepatic encephalopathy in liver cirrhosis: pathogenesis, diagnosis and management. Drugs 2000;60:1353-70

[12] Lockwood A, Yap E, Wong W. Cerebral ammonia metabolism in patients with severe liver disease and minimal hepatic encephalopathy. J Cereb Blood Flow Metab 1991;11:337-341.

[13] Gerber T, Schomerus H. Hepatic encephalopathy in liver cirrhosis: pathogenesis, diagnosis and management. Drugs 2000;60:1353-70 
[14] Butterworth RF. Complications of cirrhosis III. Hepatic encephalopathy. J Hepatol 2000;32:171-80

[15] Pilbeam CM, Anderson RM, Bhathal PS. The brain in experimental portalsystemic encephalopathy. I. Morphological changes in three animal models. J Pathol 1983;140:331-45

[16] Albrecht J, Norenberg MD. Glutamine: a Trojan horse in ammonia neurotoxicity. Hepatology 2006;44:788-94.

[17] Shawcross DL, Olde Damink SW, Butterworth RF, Jalan R. Ammonia and hepatic encephalopathy: the more things change, the more they remain the same Metab Brain Dis. 2005 Sep;20(3):169-79

[18] Ha"ussinger D, Kircheis G, Fischer R, et al. Hepatic encephalopathy in chronic liver desease: a clinical manifestation of astrocyte swelling and low grade cerebral edema. J Hepatol 2000;32:1035-8.

[19] Tanigami H, Rebel A, Martin LJ, et al. Effect of glutamine synthetase inhibition on astrocyte swelling and altered astroglial protein expression during hyperammonemia in rats. Neuroscience 2005;131:437-49.

[20] Cordoba J, Alonso J, Rovira A, Jacas C, Sanpedro F, Castells L, et al. The development of low-grade cerebral oedema in cirrhosis is supported by the evolution of $1 \mathrm{H}$ magnetic resonance abnormalities after liver transplantation.J Hepatol 2001;35:598604.

[21] Schliess F, Foster N, Gorg B, et al. Hypoosmotic swelling increases protein tyrosine nitration in cultured rat astrocytes. Glia 2004;47:21-9.

[22] Murthy CR, Rama Rao KV, Bai G, et al. Ammonia-induced production of free radicals in primary cultures of rat astrocytes. J Neurosci Res 2001;66:282-8.

[23] Jayakumar AR, Rama Rao KV, Schousboe A, et al. Glutamine-induced free radical production in cultured astrocytes. Glia 2004;46:296-301.

[24] Rama Rao KV, Chen M, Simard JM, et al. Suppression of ammonia-induced astrocyte swelling by cyclosporin A. J Neurosci Res 2003;74:891-7.

[25] Rama Rao KV, Norenberg MD. Aquaporin-4 in hepatic encephalopathy. Metab Brain Dis 2007;22:265-75.

[26] Chepkova AN, Sergeeva OA, Haas HL. Taurine rescues hippocampal long-term potentiation from ammonia-induced impairment. Neurobiol Dis 2006;23:512-21.

[27] Weissenborn K, Bokemeyer M, Ahl B, et al. Functional imaging of the brain in patients with liver cirrhosis. Metab Brain Dis 2004;19:269-80.

[28] Balata S, Olde Damink S, Ferguson K, Marshall I, Hayes P, Deutz N, et al. Induced hyperammonemia alters neuropsychology, brain MR spectroscopy and magnetization transfer in cirrhosis. HEPATOLOGY 2003;37:931-939.

[29] Fessel JN, Conn HO. An analysis of the causes and prevention of hepatic coma. Gastroenterology. 1972;62:191.

[30] Blei AT, Cordoba J. Hepatic encephalopathy. Am J Gastroenterol 2001; 96: 1968-76

[31] Schrier RW, Gross P, Gheorghiade M, et al. Tolvaptan, a selective oral vasopressin V2receptor antagonist, for hyponatremia. N Engl J Med 2006;355: 2099-112

[32] Sundaram V, Shaikh OS. Hepatic encephalopathy: pathophysiology and emerging therapies. Med Clin North Am. 2009 Jul;93(4):819-36.

[33] Riggio O, Balducci G, Ariosto F, et al. Lactitol in prevention of recurrent episodes of hepatic encephalopathy in cirrhotic patients with portal-systemic shunt. Dig Dis Sci 1989; 34 (6): 823-9 
[34] Morgan MY, Hawley KE. Lactitol vs. lactulose in the treatment of acute hepatic encephalopathy in cirrhotic patients: a double-blind, randomized trial. Hepatology 1987; 7 (6): 1278-84

[35] Heredia D, Tere's J, Orteu N, et al. Lactitol vs. lactulose in the treatment of chronic recurrent portal-systemic encephalopathy. J Hepatol 1988; 7: 106-10

[36] Cordo' ba J, Blei AT. Treatment of hepatic encephalopathy. Am J Gastroenterol 1997; 92 (9): 1429-39

[37] Clausen MR, Mortensen PB. Lactulose, disaccharides and colonic flora: clinical consequences. Drugs 1997; 53 (6): 930-42

[38] Eroglu Y, Byrne W. Hepatic encephalopathy. Emerg Med Clin N Am 2009; 27: 401-14

[39] Simmons F, Goldstein H, Boyle JD. A controlled clinical trial of lactulose in hepatic encephalopathy. Gastroenterology 1970;59:827-32.

[40] Rodgers JB Jr, Kiley JE, Balint JA. Comparison of results of long-term treatment of chronic hepatic encephalopathy with lactulose and sorbitol. Am J Gastroenterol 1973;60:459-65.

[41] Corazza GR, Tacconi C, Zoli G, Somarolli M, D'Ambro A, Bernardi M. Use of pyridoxine-alpha-ketoglutarate (PAK) in hepatic encephalopathy. Int J Clin Pharmacol Res 1982;2:7-13.

[42] Uribe M, Campollo O, Vargas F, Ravelli GP, Mundo F, Zapata L. Acidifying enemas (lactitol and lactose) vs. nonacidifying enemas (tap water) to treat acute portalsystemic encephalopathy: a double-blind, randomized clinical trial. Hepatology 1987;7:639-43.

[43] Horsmans Y, Solbreux PM, Daenens C, et al. Lactulose improves psychometric testing in cirrhotic patients with subclinical encephalopathy. Aliment Pharmacol Ther 1997; 11 (1): 165-70

[44] Watanabe A, Sakai T, Sato S, et al. Clinical efficacy of lactulose in cirrhotic patients with and without subclinical hepatic encephalopathy. Hepatology 1997; 26 (6): 1410-4

[45] Dhiman RK, Sawhney MS, Chawla YK, et al. Efficacy of lactulose in cirrhotic patients with subclinical hepatic encephalopathy. Dig Dis Sci 2000; 45 (8): 1549-52

[46] Prasad S, Dhiman RK, Duseja A, et al. Lactulose improves cognitive functions and health-related quality of life in patients with cirrhosis who have minimal hepatic encephalopathy. Hepatology 2007; 45 (3): 549-59

[47] Mas A, Rodés J, Sunyer L, Rodrigo L, Planas R, Vargas V, et al Comparison of rifaximin and lactitol in the treatment of acute hepatic encephalopathy: results of a randomized, double-blind, double-dummy, controlled clinical trial J Hepatol. 2003 Jan;38(1):51-8

[48] Als-Nielsen B, Gluud LL, Gluud C. Non-absorbable disaccharides for hepatic encephalopathy: systematic review of randomised trials. BMJ. 2004 May 1;328(7447):1046

[49] Als-Nielsen B, Gluud LL, Gluud C. Nonabsorbable disaccharides for hepatic encephalopathy Cochrane Database Syst Rev. 2004;(2):CD003044

[50] Sharma P, Sharma BC, Sarin SK. Predictors of nonresponse to lactulose in patients with cirrhosis and hepatic encephalopathy Eur J Gastroenterol Hepatol. 2010 May;22(5):526-31

[51] Sharma P, Sharma BC, Sarin SK Predictors of nonresponse to lactulose for minimal hepatic encephalopathy in patients with cirrhosis Liver Int. 2009 Oct;29(9):1365-71

[52] Lanthier PL, Morgan MY. Lactitol in the treatment of chronic hepatic encephalopathy: an open comparison with lactulose. Gut 1985; 26: 415-20 
[53] Heredia D, Terés J, Orteu N, Rodés J Lactitol vs. lactulose in the treatment of chronic recurrent portal-systemic encephalopathy. J Hepatol. 1988 Aug;7(1):106-10

[54] Morgan MY, Alonso M, Stanger LC. Lactitol and lactulose for the treatment of subclinical hepatic encephalopathy in cirrhotic patients. A randomised, cross-over study. J Hepatol. 1989 Mar;8(2):208-17

[55] Riggio O, Balducci G, Ariosto F, Merli M, Pieche U, Pinto G et al Lactitol in prevention of recurrent episodes of hepatic encephalopathy in cirrhotic patients with portalsystemic shunt. Dig Dis Sci. 1989 Jun;34(6):823-9

[56] Grandi M, Sacchetti C, Pederzoli S, Celani MF A clinical comparative study of crystalline pure lactulose and powder pure lactitol in portasystemic encephalopathy of cirrhotic patients Minerva Gastroenterol Dietol. 1991 OctDec;37(4):225-30

[57] Pai CH, Huang YS, Jeng WC, Chan CY, Lee SD Treatment of porto-systemic encephalopathy with lactitol verus lactulose: a randomized controlled study. Zhonghua Yi Xue Za Zhi (Taipei). 1995 Jan;55(1):31-6

[58] Blanc P, Daures JP, Rouillon JM, Peray P, Pierrugues R et al Lactitol or lactulose in the treatment of chronic hepatic encephalopathy: results of a meta-analysis. Hepatology. 1992 Feb;15(2):222-8.

[59] Cammà C, Fiorello F, Tinè F, Marchesini G, Fabbri A et al Lactitol in treatment of chronic hepatic encephalopathy. A meta-analysis. Dig Dis Sci. 1993 May;38(5):91622.

[60] Conn HO, Leevy CM, Vlacevic ZR, Rodgers JB, Maddrey WC, Seef L. Comparison of lactulose and neomycin in the treatment of chronic portal-systemic encephalopathy. A double blind controlled trial. Gastroenterology 1977;72:573-83.

[61] Atterbury CE, Maddrey WC, Conn HO. Neomycin-sorbitol and lactulose in the treatment of acute portal-systemic encephalopathy. A controlled, double-blind clinical trial. Am J Dig Dis 1978;23:398-406

[62] Orlandi F, Freddara U, Candelaresi MT, Morettini A, Corazza GR, Di Simone A. Comparison between neomycin and lactulose in 173 patients with hepatic encephalopathy: a randomized clinical study. Dig Dis Sci 1981;26:498-506.

[63] Blanc P, Couderc M, Peray P, Liautard J, Larrey D, Michel H, et al. Lactitol versus vancomycin in the treatment of acute hepatic encephalopathy: a double blind, randomized trial [abstract]. Gut 1993;34:46.

[64] Maclayton DO, Eaton-Maxwell A. Rifaximin for treatment of hepatic encephalopathy Ann Pharmacother. 2009 Jan;43(1):77-84

[65] Mullen K, Prakash R Rifaximin for the treatment of hepatic encephalopathy. Expert Rev Gastroenterol Hepatol. 2010 Dec;4(6):665-77

[66] Festi D, Mazzella G, Orsini M et al. Rifaximin in the treatment of chronic hepatic encephalopathy: results of a multicenter study of efficacy and safety. Curr Ther Res. 1993,54(5), 598-609.

[67] Palmer M. The antibiotic rifaximin improves hepatic encephalopathy symptoms in patients with cirrhosis due to hepatitis C virus. Pract Gastroenterol.2007, 31(2), 7276

[68] Puxeddu A, Quartini M, Massimetti A, Ferrieri A. Rifaximin in the treatment of chronic hepatic encephalopathy. Curr Med Res Opin.1995, 13(5), 274-281

[69] Sama C, Morselli-Labate AM, Pianta P, Lambertini L, Berardi S, Martini G. Clinical effects of rifaximin in patients with hepatic encephalopathy intolerant or 
nonresponsive to previous lactulose treatment: an open-label, pilot study. Curr Ther Res.2004, 65(5), 413-422

[70] Bucci L, Palmieri GC. Double-blind, double-dummy comparison between treatment with rifaximin and lactulose in patients with medium to severe degree hepatic encephalopathy. Curr Med Res Opin. 1993,13(2), 109-118

[71] Loguercio C, Federico A, De Girolamo V, Ferrieri A, Del Vicchio BD. Cyclic treatment of chronic hepatic encephalopathy with rifaximin. Results of a double-blind clinical study. Minerva Gastroenterol Dietol 2003;49:53-62

[72] Massa P, Vallerino E, Dodero M. Treatment of hepatic encephalopathy with rifaximin: double blind, double dummy study versus lactulose. Eur J Clin Res.1993; 4, 7-18

[73] Mas A, Rodes J, Sunyer L, Rodrigo L, Planas R, Vargas V. Comparison of rifaximin and lactitol in the treatment of acute hepatic encephalopathy: results of a randomized, double-blind, double-dummy, controlled clinical trial. J Hepatol 2003;38:51-8.

[74] Fera G, Agostinacchio F, Nigro M, et al. Rifaximin in the treatment of hepatic encephalopathy. Eur J Clin Res 1993;4: 57-66

[75] Leevy CB, Phillips JA. Hospitalizations during the use of rifaximin versus lactulose for the treatment of hepatic encephalopathy. Dig Dis Sci 2007; 52: 737-41

[76] Paik $\mathrm{YH}$, Lee KS, Han $\mathrm{KH}$, et al. Comparison of rifaximin and lactulose for the treatment of hepatic encephalopathy: a prospective randomized study. Yonsei Med J 2005; 46 (3):399-407

[77] Leevy CB, Phillips JA. Hospitalizations during the use of rifaximin versus lactulose for the treatment of hepatic encephalopathy Dig Dis Sci. 2007 Mar;52(3):737-41

[78] Jiang Q, Jiang $\mathrm{XH}$, Zheng $\mathrm{MH}$, Jiang LM, Chen YP, Wang L. Rifaximin versus nonabsorbable disaccharides in the management of hepatic encephalopathy: a meta-analysis Eur J Gastroenterol Hepatol. 2008 Nov;20(11):1064-70

[79] Mantry PS, Munsaf S. Does the addition of rifaximin to lactulose reduce the severity of hepatic encephalopathy? A single-center experience [abstract] Hepatology. 2008;48:517A, \#472.

[80] Mantry PS, Munsaf S. Comparison of tolerability of adjunctive rifaximin treatment versus lactulose monotherapy for hepatic encephalopathy [abstract] Hepatology. 2008;48:518A, \#473.

[81] Mittal VV, Sharma BC, Sharma P, Sarin SK. A randomized controlled trial comparing lactulose, probiotics, and L-ornithine L-aspartate in treatment of minimal hepatic encephalopathy Eur J Gastroenterol Hepatol. 2011 Aug;23(8):725-32

[82] Sharma P, Sharma BC, Puri V, Sarin SK. An open-label randomized controlled trial of lactulose and probiotics in the treatment of minimal hepatic encephalopathy Eur J Gastroenterol Hepatol. 2008 Jun;20(6):506-11

[83] Malaguarnera M, Gargante MP, Malaguarnera G, Bifidobacterium combined with fructo-oligosaccharide versus lactulose in the treatment of patients with hepatic encephalopathy Eur J Gastroenterol Hepatol. 2010 Feb;22(2):199-206)

[84] Loguercio C, Del Vecchio Blanco C, Coltorti M. Enterococcus lactic acid bacteria strain SF68 and lactulose in hepatic encephalopathy: a controlled study. J Int Med Res. 1987 Nov-Dec;15(6):335-43

[85] Loguercio C, Abbiati R, Rinaldi M, Romano A, Del Vecchio Blanco C et al Long-term effects of Enterococcus faecium SF68 versus lactulose in the treatment of patients with cirrhosis and grade 1-2 hepatic encephalopathy. J Hepatol. 1995 Jul;23(1):39-46 
[86] Sushma S, Dasarathy S, Tandon RK, Jain S, Gupta S, Bhist MS Sodium benzoate in the treatment of acute hepatic encephalopathy: a double-blind randomized trial. Hepatology. 1992 Jul;16(1):138-44

[87] Efrati C, Masini A, Merli M, Valeriano V, Riggio O Effect of Sodium Benzoate on Blood Ammonia Response to Oral Glutamine Challenge in Cirrhotic Patients: A Note of Caution Am J Gastroenterol 2000;95:3574 -3578

[88] Fiaccadori F, Ghinelli F, Pelosi G, Sacchini D, Vaona GL, Zeneroli ML et al Selective amono acid solutions in hepatic encephalopathy treatment (a preliminary report). Ric Clin Lab. 1980 Apr-Jun;10(2):411-22

[89] Rossi-Fanelli F, Riggio O, Cangiano C, Cascino A, De Conciliis D, Merli M et al Branched-chain amino acids vs lactulose in the treatment of hepatic coma: a controlled study. Dig Dis Sci. 1982 Oct;27(10):929-35

[90] Als-Nielsen B, Koretz RL, Kjaergard LL, Gluud C. Branched-chain amino acids for hepatic encephalopathy Cochrane Database Syst Rev. 2003;(2):CD001939

[91] Romero-Gomez M, Boza F, Garcia-Valdecasas MS, García E, Aguilar-Reina J. Subclinical hepatic encephalopathy predicts the development of overt hepatic encephalopathy. Am J Gastroenterol 2001;96:2718-2723

[92] Das A, Dhiman RK, Saraswat VA, Verma M, Naik SR. Prevalence and natural history of subclinical hepatic encephalopathy in cirrhosis. J Gastroenterol Hepatol 2001;16:531 535.

[93] Hartmann IJ, Groeneweg M, Quero JC, Beijeman SJ, de Man RA, Hop WC et al. The prognostic significance of subclinical hepatic encephalopathy. Am J Gastroenterol 2000; 95: 2029-34.

[94] Sharma P, Agrawal A, Sharma BC, Sarin SK Prophylaxis of Hepatic Encephalopathy in Acute Variceal Bleed: A Randomized Controlled Trial of Lactulose versus no Lactulose J Gastroenterol Hepatol. 2010

[95] Sharma P, Agrawal A, Sharma BC, Sarin SK. Primary prophylaxis of hepatic encephalopathy in patients with cirrhosis: an open labeled randomized controlled trial of lactulose versus no lactulose. Indian J Gastroenterol 2010; 29 (Suppl 1): A8

[96] Riggio O, Masini A, Efrati C, et al. Pharmacological prophylaxis of hepatic encephalopathy after transjugular intrahepatic portosystemic shunt: a randomized controlled study. J Hepatol 2005; 42: 674-9

[97] Sharma BC, Sharma P, Agrawal A, et al. Secondary prophylaxis of hepatic encephalopathy: an open-label randomized controlled trial of lactulose versus placebo. Gastroenterology 2009; 137: 885-91

[98] Bass NM, Mullen KD, Sanyal A, et al. Rifaximin treatment in hepatic encephalopathy. N Engl J Med 2010; 362 (12): 1071-81

[99] Sanyal A, Younossi ZM, Bass NM, Mullen KD, Poordad F, Brown RS, et al Randomised clinical trial: rifaximin improves health-related quality of life in cirrhotic patients with hepatic encephalopathy - a double-blind placebo-controlled study Aliment Pharmacol Ther. 2011 


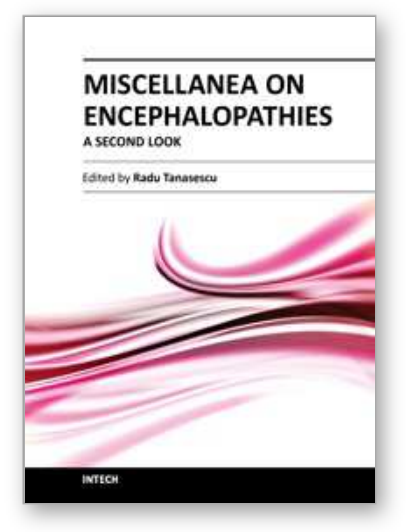

\author{
Miscellanea on Encephalopathies - A Second Look \\ Edited by Dr. Radu Tanasescu
}

ISBN 978-953-51-0558-9

Hard cover, 390 pages

Publisher InTech

Published online 25, April, 2012

Published in print edition April, 2012

The book project "Miscellanea on Encephalopathies-a second look" aims to cover some of the important aspects regarding metabolic, hypoxic, neoplasm- and drug-related encephalopathies, by transmitting valuable information filtered through the real life clinical and research experience of the authors.

\title{
How to reference
}

In order to correctly reference this scholarly work, feel free to copy and paste the following:

Praveen Sharma (2012). Disaccharides in the Treatment of Hepatic Encephalopathy in Patients with Cirrhosis, Miscellanea on Encephalopathies - A Second Look, Dr. Radu Tanasescu (Ed.), ISBN: 978-953-51-0558-9, InTech, Available from: http://www.intechopen.com/books/miscellanea-on-encephalopathies-a-secondlook/disaccharides-in-the-treatment-of-hepatic-encephalopathy

\section{INTECH}

open science | open minds

\section{InTech Europe}

University Campus STeP Ri

Slavka Krautzeka 83/A

51000 Rijeka, Croatia

Phone: +385 (51) 770447

Fax: +385 (51) 686166

www.intechopen.com

\section{InTech China}

Unit 405, Office Block, Hotel Equatorial Shanghai

No.65, Yan An Road (West), Shanghai, 200040, China 中国上海市延安西路65号上海国际贵都大饭店办公楼 405 单元

Phone: +86-21-62489820

Fax: +86-21-62489821 
(C) 2012 The Author(s). Licensee IntechOpen. This is an open access article distributed under the terms of the Creative Commons Attribution 3.0 License, which permits unrestricted use, distribution, and reproduction in any medium, provided the original work is properly cited. 